\title{
UNIVERSITYOF
}

FORWARD

THINKING

WESTMINSTER ${ }^{\text {用 }}$

WestminsterResearch

http://www.westminster.ac.uk/westminsterresearch

\section{Building the layers of a manufacturing taxonomy: how 3D printing is creating a new landscape of production eco-systems and competitive dynamics}

Kapetaniou, C., Rieple, A., Pilkington, A., Frandsen, T. and Pisano, $\mathbf{P}$.

NOTICE: this is the authors' version of a work that was accepted for publication in Technological Forecasting \& Social Change. Changes resulting from the publishing process, such as peer review, editing, corrections, structural formatting, and other quality control mechanisms may not be reflected in this document. Changes may have been made to this work since it was submitted for publication. A definitive version was subsequently published in Technological Forecasting \& Social Change, DOI:

10.1016/j.techfore.2017.10.011, 2017.

The final definitive version in Technological Forecasting \& Social Change is available online at:

https://dx.doi.org/10.1016/j.techfore.2017.10.011

(C) 2017. This manuscript version is made available under the CC-BY-NC-ND 4.0 license http://creativecommons.org/licenses/by-nc-nd/4.0/

The WestminsterResearch online digital archive at the University of Westminster aims to make the research output of the University available to a wider audience. Copyright and Moral Rights remain with the authors and/or copyright owners.

Whilst further distribution of specific materials from within this archive is forbidden, you may freely distribute the URL of WestminsterResearch: ((http://westminsterresearch.wmin.ac.uk/). 
In case of abuse or copyright appearing without permission e-mail repository@westminster.ac.uk 


\title{
Building the layers of a manufacturing taxonomy: how 3D printing is creating a new landscape of production eco-systems and competitive dynamics
}

\begin{abstract}
Recent innovations in 3D printing technologies and processes have influenced how products are designed, built and delivered. However, there is a significant gap in our knowledge of how 3D printing is impacting on manufacturing eco-systems within different industries and contexts. Drawing inspiration from earlier manufacturing taxonomies as well as the competitive dynamics literature which provides insights into industries' moves from straightforwardly rivalrous frameworks, through competitive-cooperative exemplars, into the more recent relational-based competition. Basing our analysis on a systematic review of organisations' use of 3D printing, we develop a new taxonomy explaining the many areas the technology can impact. In addition to offering a comprehensive framework to conceptualise the impact of 3D printing, we emphasise the role of users in co-creation and personalisation. While 3D printing has been touted as disruptive, we suggest that our new taxonomy offers a richer understanding of the ways firms can operate in a $3 \mathrm{D}$ printing context. We furthermore apply the relational competition category of the competitive dynamics model to our taxonomy, showing how 3D printing influences the modes and aims of competition, roster of actors and action toolkits within the different industry sectors.
\end{abstract}

Keywords: 3D printing; Industrial taxonomies; Competitive Dynamics; Production ecosystems

\section{Introduction}

Rapidly increasing developments in automation technologies, including 3D printing, have changed how products are designed, built and delivered. However, there is still not a clear-cut answer about the impact of this new wave of technological progress on existing market structures. In this paper we address the significant gap in knowledge of how 3D (three-dimensional) ${ }^{1}$ printing is impacting manufacturing ecosystems. Drawing inspiration from earlier taxonomies of sectoral patterns of innovation (e.g. Pavitt, 1984; Miozzo and Soete, 2001; Castellacci, 2008)), we offer a framework for plotting and comparing the impact of 3D printing. Basing our analysis on case studies of more than 20 firms we construct a taxonomy to accommodate

\footnotetext{
${ }^{1}$ We know that there are discussions both in the literature and in industry about the differences between additive manufacturing and 3D printing. For the sake of coherence and brevity in this paper we use the term 3D printing to encompass both types, except where it is important to make a distinction between the two.
} 
developments in $3 \mathrm{D}$ printing and show how these are changing the rules of the game and competitive dynamics in different industry sectors. In so doing we are contributing to the advances made in the literature on competitive dynamics where the move from rivalrous frameworks through competitive-cooperative dynamics, to relative competition (Chen and Miller, 2012, 2015; Ghemawat and Cassiman, 2007) is clearly evident in the cases we present. We also emphasise the role of users in cocreation and personalisation and how this varies according to the level of use of 3D printing at different stages between end products and various types of manufacturing strategies.

$3 \mathrm{D}$ printing refers to "a process of joining materials to make objects from $3 \mathrm{D}$ model data, usually layer upon layer, as opposed to subtractive manufacturing methodologies" (Standard, 2012). Originally 3D printing was mainly used for prototyping (Rayna and Striukova, 2016). As the technology improved, 3D printers have found wider application, including making tools used for traditional manufacturing and the production of end-products (Royal Academy of Engineering, 2014). It provides companies with a wide range of both benefits and challenges. Firms that employ 3D printing are able to increase supply chain efficiencies, reduce time to market, move from mass production to mass customization, and sustain the environment (Ford, 2014). But it is also bringing radical change to manufacturing systems and challenges companies to reinvent their business models.

Bogers et al. (2016) argue that 3D printing is changing, and in some cases radically disrupting, power structures and supply chain dynamics. This forces firms to change and enables the startup of new firms. However, understanding these changes is a rather complicated matter (Rayna and Striukova, 2016). Limits to the size of goods produced by $3 \mathrm{D}$ printing, difficulties in achieving mass production, issues with materials, and certification standards, constrain adoption in some industries, but not others (United States Government Accountability Office, 2015). While this technology is evolving and has the potential to transform manufacturing ecosystems, a granular understanding of the socioeconomic consequences of 3D printing lags activity (Ford et al., 2016). Empirical investigations of how different industries have transitioned to, or employed, 3D printing technologies are sparse. This paper undertakes a detailed review of the application of 3D printing technologies in different manufacturing industries in order to understand the impact of 3D printing on business ecosystems and the implications for firms and customers. As such we adopted an illuminative research strategy in which we sought exemplar organisations within different types of industries in order to understand the changes that $3 \mathrm{D}$ printing has brought to their operations.

The advent of 3D printing has been seen in many different ways, such as an example of a disruptive innovation (Christensen 1997; Christensen and Raynor 2003; Rayna and Striukova, 2016), or as an accelerated move towards the digitisation of manufacturing. Its impact has been substantial, leading to radical and even Schumpeterian changes in some industries and the manufacturing landscape (Manyika et al., 2013; Petrick and Simpson, 2013; Rayna et al., 2015; Rayna and Striukova, 
2016; Schumpeter, 1939). Technological transitions such as this influence existing industries, encourage the development and expansion of new industries, and can even overthrow existing industries (Sandström, 2011; Schmidt and Druehl, 2008). Many questions remain pertaining to the fundamental impact of 3D printing and also more specifically on individual firms and industries. The technology is also a pertinent example of the competitive dynamics literature at play as we see industries moving away from the language of combat to examples reflecting the "action/reaction dyads, streams of actions and relative interdependence" described in the literature (Chen and Miller, 2012, 2015).

In addition, because of the role of digitisation, 3D printing has also been significant in newer business models and emerging industries. It has been grouped with other disrupted technologies such as digital books and music (Berman, 2012). However, there are some differences, mainly to do with the physical nature of the product: "While movies and music are nowadays predominantly transferred over the Internet to be 'manufactured' at home, it is unlikely that all manufacturing will follow this path, with every single object being fabricated at home on a personal 3D printer" (Rayna and Striukova, 2016, pp. 214-215). However, 3D printing could be used to manufacture some low volume customised products when economically attractive (Berman, 2012; Petrick and Simpson, 2013; Petrovic et al., 2011), accelerating a cultural shift towards do-it-yourself inventing and making (Anderson, 2012).

Some believe that a 3D printer will someday be in every home, making the industrial giants of the past redundant (Anderson, 2012). Easy access to materials, machines and digital software allows individuals to design and manufacture their own creations. These factors also provide significant opportunities for co-creation based around Web 2.0 technologies (Rayna and Striukova, 2015). A number of new online platforms now enable businesses, designers and individuals to crowdsource the design or manufacturing of their products. Such emerging user communities provide many opportunities to consumers, and considerable competitive challenges to existing producers (de Jong and de Bruijn 2013). As these technologies improve, they can potentially alter the structure of competition. Industry borders could be transcended and value chains disaggregated, creating new competitive dynamics (Rayna and Striukova, 2016).

$3 \mathrm{D}$ printing technologies have the potential to enable the digitalisation and democratisation of manufacturing. Thus earlier taxonomies of industries do not take into account some of the important changes 3D printing enables such as consumer involvement and competitive interactions across various industries, confronting firms and individuals with new opportunities and challenges. 3D printing technologies have enabled the personalization of products tailored to the individual needs of consumers and has accelerated the trend towards co-creation in some industries (Rayna and Striukova, 2016). Rivalrous behaviour is not limited to similar firms within the same industry but brings together competitors from different industries(Chen and Miller, 2015).

There has been limited attempt to understand how the evolution of 3D printing 
impacts firm's behaviour and contributes to the development of a new taxonomy of manufacturing industries. We extend research on previous industrial taxonomies in several ways. First, we offer an updated taxonomy based on the changes that 3D printing has enabled. We believe that an updated categorization of industries and firms based on new dimensions, including the location of production in the supply chain and consumer involvement in the development of the product and competitive dynamics, is necessary. Second, we synthesise the literature of co-creation and personalisation with technological content of earlier industry taxonomies, to understand the role of the user and supply chain firms in production. Third, we draw on the competitive dynamics literature and recognise that competitive dynamics do not only exist between homogeneous firms, and the dyadic relationship between a focal firm and its main rival is no longer sufficient for explaining a firm's competitive behaviour (Chen and Miller, 2015). Firms from previously adjacent industries are crossing industry borders and shifting position in the supply chain to compete with previously unlikely rivals. Finally, we suggest that the new taxonomy will point out the main implications of this theoretical view for individuals and firms who are considering adopting 3D printing technologies and technology manufacturers who want to know the next niche market for their products.

Through the analysis of secondary data sources on the top industrial users of 3D printing and drawing inspiration from earlier typologies, we develop a new, extended and updated, taxonomy of industry types that facilitates an understanding of how 3D printing has changed the rules of the game and competitive dynamics in different industries, both modern and traditional (Bogers et al., 2016; Jia et al., 2016). The new taxonomy is applied in order to develop an understanding of the diversity of sectors and map the differences between them (Archibugi, 2001).

As such, this article addresses three questions about the impact of $3 \mathrm{D}$ printing. First, how is 3D printing being applied in different industries? Second, what changes are happening in existing market and supply structures, and what are the implications for firms and their customers? Third, what additional understanding can a new taxonomy offer to help appreciate the ways firms can operate in a 3D printing context? Fourth, we seek to add context based data to the competitive dynamics model and its five dimensions.

The structure of this article is as follows. The next sections review the relevant literature on 3D printing and sectoral taxonomies. Section 4 describes the research design and analysis. Subsequently, sections 5 and 6 present and discuss our empirical findings. Section 7 concludes by highlighting the main implications for theory, practice and policy, and outlines avenues for further research.

\section{3D Printing Technology: Potential Implications}

Although 3D printing technology has been around since the $1980 \mathrm{~s}$, businesses are only now really beginning to realize the possibilities of using this technology 
within their business models (Bogers et al., 2016; Brooks et al., 2014). While the technology was initially used as a prototyping tool it has increasingly been used in wider applications (United States Government Accountability Office, 2015). As the technology has advanced, its use has expanded into the production of tools, direct production of goods, and at-home fabrication (Rayna and Striukova, 2016). Tool fabrication with 3D printing offers a number of benefits. It reduces costs by decreasing the material scrap during construction, improves functionality by producing complex shapes, and supports user customisation (Cotteleer et al., 2014). Technology improvement is shifting the focus from fabricating prototypes and tooling to the production of functional parts and products (see Figure 1).

\section{INSERT FIGURE 1 ABOUT HERE}

Fundamentally, 3D printing provides companies and consumers with numerous benefits. Hyper flexibility can provide cost benefits as it reduces supply chain complexity and shortens design processes (Bogers et al., 2016). It also reduces fixed assets such as tooling and decreases risk in new product innovation (Reeves and Mendis, 2015), and enables manufacturers to produce cost effectively at low volumes for products with highly complex shapes that cannot be made by traditional methods. It has been argued that the technology is unlikely to replace traditional mass production anytime soon, but its impact on increasing variety can affect the cost base of many industries (Holmström et al., 2016). In conventional manufacturing, mass production and fast repetition favour standardisation making time-consuming and expensive to produce small volumes unprofitable (Ford, 2014). However, 3D printing produces on demand resulting in increased supply chain efficiency, reducing material waste, and mitigating environmental impacts (Ford, 2014). In addition, in some cases it enables the consumer to engage directly with the production process and allows manufacturing to move from mass production to mass customisation and personalisation (e.g., Bogers et al., 2016; Piller at al., 2015). The value of a shift towards 3D printing for end products differs in each industry, as we discuss later, but the reasons include: the monetising of the long tail (Anderson, 2008), decreasing setup costs, shifts in the location of production and the increasing role for the user in the production process.

A 3D printer enables the monetising of the 'long tail' (Anderson, 2008) as traditional manufacturing neglects niche market segments due to the high initial manufacturing costs. 3D printers remove the volume requirements of production setup costs, allowing for niche market segments to be exploited. Although mass manufacturers may eventually be interested in substituting or supplementing existing practices of mass production with 3D printing, we do not yet know in which industries or markets they are likely to be found or what the limitations of the 3D printing technologies in these sectors are (Holmström et al., 2016). According to Ford (2014), lengthy build times, size of objects that can be made and issues with materials have significantly limited the application of 3D printing in several sectors such as 
aerospace and defence.

3D printing technology has been touted as supporting the development of disruptive innovations. According to Downes and Nunes (2013) when a firm finds the right combination of technologies with the right business model, its impact can be immediate. Consumers learn about the product, adopt it immediately and as the technology becomes more efficient further firms and startups create more industry disruptions (Grynol, 2013). 3D printing may provide new opportunities for startups and individual entrepreneurs, disrupting incumbents which are not sufficiently nimble or lacking skills in core areas necessary to compete. 3D printers have become inexpensive enough to be used by individuals and smaller businesses. The barriers in the past of accessing mass-manufacturing facilities because of a lack of sufficient funds, may disappear (Rayna and Striukova, 2016). As such, 3D printing could have an impact favouring smaller firms without a large capital base as they not need to setup costly production process, and often are able to receive money up-front (Rayna and Striukova, 2016). This is just one way 3D printing can allow experimentation and the entry of new firms increasing competition (Jia et al., 2016; Reeves and Mendis, 2015).

It is also possible for consumers to be involved in the design and creation of customized products (Rayna et al., 2015; Rayna and Striukova 2016) and enabling crowdsourcing (Howe, 2006) within manufacturing. The fact that 3D printing provides highly customizable and personalizable products implies a potential shift of value-adding activities from the manufacturer to consumer. This therefore presents an alternative logic for creating value (e.g., Bogers et al., 2016; Piller et al., 2015) as the distinction between consumers and producers has become increasingly blurred (Firat and Venkatesh, 1995). Consumers can no longer be viewed as outside the firm (Prahalad and Ramaswamy, 2004). Bogers et al. (2016) argue that 3D printing will complement traditional manufacturing-centric business models with a more consumer-centric business model in which consumers may even replace workers for some aspects of the production chain (Ritzer and Jurgenson, 2010). Traditional distribution models based on the vertical relationships between producers and distributors can also be reconfigured into open/decentralised systems in some cases (Baden-Fuller and Haefliger, 2013).

3D printing can be used not just by traditional manufacturers, but also by their customers, enabling them to test ideas and thereby increasing competition (Rayna and Striukova, 2016). The line between consumer and producer becomes blurred, allowing for the democratisation of manufacturing and increasing competition. 3D printing could replace the economies-of-scale of traditional manufacturers with economies-of-one production, at least for some industries, eliminating entry barriers and changing the competitive rules of the game. Industry boundaries might even disappear (Rayna and Striukova, 2016).

In order to address developments such as this scholars such as Chen (1996) and Chen and Miller (2015) have developed frameworks that model the aspects of the competitive environment that shape what players can and cannot do. The awareness- 
motivation-capability (AMC) framework of Chen (1996) provides an integrative model of the behavioural drivers that explain a competitor's actions and responses. A competitor will not be able to engage in competitive activity unless it is aware of the competitive environment, motivated to react, and capable of implementing competitive reactions.

The AMC model can be combined with the characteristics of industries to predict the sources and consequences of firms' behavior (Chen and Miller, 2015). Chen and Miller's multidimensional framework contrasts three prototypical views of competitive dynamics-rivalrous, competitive-cooperative, and relational. In addition, they proposed that firms might also adopt a hybrid structure that does not represent purely rivalrous or relational archetypes. Chen and Miller (2015) contrast the three modes of competition based on five dimensions- aims of competition, mode of competing, roster of actors, action toolkit, and time horizon of interaction. Of these the relational is the most relevant for our argument, as we discuss further below. In a relational view of competitive dynamics, the aim is to benefit many kinds of market players; the mode is to cooperate and compete simultaneously rather than to only attack or cooperate. The relational toolkit is not only economic, but political, social and ideological as well; and the time horizon is short term to build for the long term and vice versa, as against relatively short-term or intermediate in a purely rivalrous or competitive-cooperative relationship. However, although the concept of competitive dynamics has received considerable attention in the academic literature and the relational category has some attractions for our discussion, there are few compelling explanations of how new automation technologies such as 3D printing might affect the competitive dynamics between firms. For example, 3D printing could blur the boundaries of industries and stimulate the convergence of sectors, contributing to the awareness, motivation and opportunities to compete relationally. In fact, we would argue that $3 \mathrm{D}$ printing, through the new industry characteristics that has accompanied it, is a fine context to explore Chen and Miller's (2015) models of competitive dynamics, especially their relational category. There appears to be a marked move away from rivalrous competition and evidence of much much cooperation and relational competition. In this the modes of competing, the changing roster of actors, and new action tool kits are evidence of profound changes to industry structure, business models and the location of both power and innovation. This is a very different landscape than that captured in previous lenses.

At the moment 3D technology is found mainly in automotive, consumer products, medical and aerospace industries (see Table 2). Adoption has been limited by the cost, availability and quality of raw materials, as well as the accuracy and strength of 3D-printed products (Berman, 2012; Brooks et al., 2014; Petrovic et al., 2011). As cost drops and quality improves 3D printing is likely to expand beyond its present scope (Berman, 2012), but by and large, 3D printing and rapid manufacturing largely remains limited to small volume production (Ford, 2014). While the technology scope is growing, its implications for overall manufacturing are not clear. There have been few systematic empirical studies on the impact of $3 \mathrm{D}$ printing on the 
manufacturing eco-system and the firms within it (Bogers, 2016; Jia et al., 2016).

\section{INSEFRT TABLE 1 ABOUT HERE}

In a rare example, Jia et al. (2016) evaluated the supply chain effects of food manufacturers and retailers adopting 3D printing in the processed food industry. Their study indicated that $3 \mathrm{D}$ printing is a distributive technology to chocolate manufacturers. The authors argued that manufacturers risk being left out of the market if retailers adopt this technology and successfully sell directly customized chocolates. Bogers et al. (2016) studied the case of a consumer goods manufacture and showed that emerging 3D printing technologies impacted business model development and operations. The technology can change the role of the consumer within the business model, transforming the supply chain into a more distributed form. On the other hand, Sandström (2016) showed that although 3D printing resulted in substantial cost savings and quality improvements for manufacturers, the new technology did not have any impact on competitive dynamics and could be considered an example where the technology was not disruptive but incremental and available to all. This highlights one difficulty with claiming that $3 \mathrm{D}$ printing is always disruptive and focussing our understanding on just this point of leverage as we must always understand the industry context to draw conclusions. We investigate how this can be overcome in the next section.

\section{Taxonomies of Sectoral Patterns}

As we show above, while some suggest that the introduction of $3 \mathrm{D}$ printing will have significant impact on market structures and competitive dynamics (Chen and Miller, 2015; Bogers et al., 2016; Jia et al., 2016), it is not possible to generalize these findings to all industries. Existing sector taxonomies show that innovation modes, collaborations, knowledge sources, and therefore business models differ according to industry (Archibugi, 2001). Taxonomies illustrate what "firms can and cannot do" (Pavitt, 1998, p.441).Previous taxonomies, however, do not take into account some of the important changes 3D printing has brought about such as consumer involvement, relocation of production, reduction in break-even volumes and alternative design solutions. Therefore, a better and more complete understanding of firms' behaviour based on 3D technology is warranted; 3D printing demands a new updated categorisation of industries and firms that includes issues of consumer involvement in the production process, competitive dynamics, and technological content. Following this, we propose a taxonomy based on many existing examples to help explore 3D printing impact.

One of the most influential of previous taxonomies of sectoral patterns, Pavitt's (1984), describes the behaviour of innovating firms, predicts their actions as a consequence, and suggests a framework for policy analysis (Archibugi, 2001). 
Pavitt's taxonomy presents patterns of innovation in different categories and presents a theory of innovation flow among the different sector types (Figure 2). The first category, supplier-dominated firms, tend to be small firms found in traditional industries such as textile and furniture. They typically focus on productivity and acquire most of their technology from outside the firm, from science-based firms and scale-intensive firms. The second category, scale-intensive firms, are often large and oligopolistic. They focus on the increase of the scale and speed of production to exploit economies of scale. Innovation is mostly undertaken within their production departments and they often receive technology from science-based firms. The third category is the science-based sector, which includes firms that rely on internal R\&D and have universities and research centres as sources of innovation. The last classification, specialised supplier firms, tend to be small firms which rely on batch production. They produce technology to be sold and supply specialised machinery and tools to their scale-intensive and supplier-dominated customers. Technological linkages among different groups of sectors include transactions involving goods, information, and technological diversification (Pavitt, 1984).

\section{INSERT FIGURE 2 ABOUT HERE}

However Pavitt was limited in his focus, ignoring innovation in services. Many studies had suggested that not only manufacturing firms but also service firms could have differentiated patterns of innovation (Evangelista, 2000; Miles, 1993; Miozzo and Soete, 2001). A subsequent taxonomy was then developed by Castellacci (2008) who offered an integrated classification of manufacturing and service sectors which encompassed the role of external players from the supply and design chains such as users and also the more open business models that were emerging then (see Figure 3).

Previous taxonomies have used different ways to categorise firms. Castellacci, for example, focused on vertical linkages, i.e. the set of relationships and interactions in terms of advanced knowledge, material inputs between producers, suppliers and users of new technologies (Castellacci, 2008). His use of the term vertical chain focuses on the position of the sector in the ecosystem as provider or recipient of the product (Figure 3). Most typologies have also taken a product market view suggesting that a shared-market industry raises competitive activity between the homogenous firms (Chen, 1996; Chen and Miller, 2012; Gimeno et al., 2006).

\section{INSERT FIGURE 3 ABOUT HERE}

We argue that all previous industrial taxonomies are not properly able to conceptualise and map the relationships between firms and industries using 3D technologies. Therefore, in order to understand the profound changes brought about 
by 3D printing in some sectors, but not others, and include all categories of industry (for example services and manufacturing), our taxonomy focuses on those sectors that our data show are principal users of the technology (Wohlers, 2017).

A number of the aspects of previous taxonomies suggest the need for a new one. For example. the vertical chain of Castellacci's model is to all intents and purposes irrelevant in the 3D printing ecosystem; the position of each industry within the ecosystem is not static, but may take various forms. For example, suppliers of 3D technologies (specialised suppliers) are not always at the bottom of the vertical chain as they also provide printers to individuals who are able to produce their own goods. In addition, supplier dominated firms are not only in the higher level of the vertical chain as they could choose to sell intermediate goods, such as design, to online platforms that also sell the outputs from knowledge intensive business services.

Scale is also an issue. Previous taxonomies have assumed that smaller firms benefit from internal conditions such as flexibility that enable rapid decision-making processes about new ideas, products and technologies, and the hiring of new employees (Lewin and Massini, 2003; Schumpeter, 1942). Larger firms are assumed to have many resources focused on old technologies which are too expensive to convert to a new one (Henderson and Clark, 1990). However, they might be in a position to invest in a new technology and try it out while keeping the old technology minimising the risk of failure, an option unavailable to small firms who are less likely to have the financial resources required to invest in a new technology (HewittDundas 2006). 3D printing, in contrast, is usable by large firms and small firms alike. 3D printing allows the replacement of the traditional economies of-scale production of large manufacturers with economies-of-one production, at least for some industries, thereby eliminating firm size advantages. Thus at least one of the defining characteristics included in Castellacci's taxonomy, the size of firms, is not relevant to 3D printing, although other aspects included in his category of technological content are relevant, and are likely to determine the applications of 3D printing in various industries.

Previous taxonomies have mainly focused on the dyadic relationships between a focal firm and its partners, and failed to take into sufficient account the environmental context which co-determines firms' competitive actions (Chen and Miller, 2015; Ghemawat and Cassiman, 2007). This is so because 3D printing is not confined to a single industry, but brings together companies in competitive, collaborative and complementary relationships from different industries (Chen and Miller, 2012; 2015). The dyadic relationship between a focal firm and its main rival is no longer sufficient for explaining the firm's competitive behaviour (Zucchini and Kretschmer, 2011) as 3D printing is, in some settings, confronting firms and individuals with new opportunities and challenges (Prahalad and Ramaswamy, 2004).

Although consumers have been involved in all stages of the production process, from design to manufacturing and distribution, this has normally been only to a limited extent. 3D printing has enabled the increased participation of the user in the production process and has accelerated the trend towards co-creation (Rayna et al., 
2015). This blurs the line between consumption and production activities (Firat and Venkatesh, 1995), thus it is useful for a taxonomy to distinguish different forms of consumer involvement; co-creation, personalisation and mass customisation. 3D printing technologies enable the personalization of products tailored to the individual needs of consumers and customers are becoming a part of the value network in some industries (Rayna and Striukova, 2016). As Prahalad and Ramaswamy (2004) argue consumers should no longer be viewed as outside the firm. Co-creation often results in mass customisation. Mass customisation is associated with the production of personalised or tailored products on a large scale (Rayna et al., 2015). While personalization is about using information for an individual and negotiating the selection with the individual, customization relates to modifying product or service components according to customers' needs and desires. The level of user participation in the production process may not be homogeneous for all industries; limits on the size of goods or mass production by 3D printing (Ford, 2014) may limit the production of some products and the possibility of co-creation and personalisation in some sectors.

The initial analysis of our data was simplified by placing our companies into one of four groups of industries adopted from the prior industrial taxonomies literatures. Our four categories are 1) supplier-dominated; 2) scale-intensive; 3) science-based; and 4) specialist suppliers. The major dimensions used to categorise these firms included: nature, sources and patterns of innovation as well as firm size and market structure. Subsequently we found that we needed to add one dimension which our data indicated appeared particularly material to 3D printing, consumer involvement in the product development process. In the following sections we explain our methodology and justify our categorization.

\section{Research Design and Analysis}

A systematic review of secondary data was undertaken to identify the main industries using 3D printing. We used multiple sources to identify relevant industries, including industry consultants' reports (e.g., Wohlers, 2012, 2014, 2017), academic journals (e.g., Technological Forecasting and Social Change), and government reports (e.g., Ford, 2014). These reports and articles were identified in databases and search engines using the following keywords: 1) "3d-printing", 2) " $3 \mathrm{~d}$ printing", and 3) "additive manufacturing". They were reviewed to describe the technological potential and main production applications of 3D printing, the most recurrent cases of its use, and the main industries represented. We also searched for articles within Factiva, the international newspaper and magazine database, from the period beginning in January 2010, when 3D printing started to take off, to June 2016, using these keywords. We identified around 40,000 articles using the first two keywords and 17,000 using the third. Factiva categorises these articles within broader industries out of which we selected to review the most popular ones, which comprise 30,000 
articles approximately, that were also mentioned in academic journals and consultants' reports.

Our data show that consumer products, consumer electronics, automotive, aerospace, medical/dental, industrial/business machines, material suppliers and KIBS are the main industries to have embraced 3D printing. We decided that the consumer products category, as used by a number of authors, was too broad for our purposes (Ford, 2014; Reeves and Mendis, 2015) and so focussed on the most important subcategories, including clothing/textiles and artistic products such as jewellery. From academic journals in particular we found one industry that does not appear within any of the Factiva codes, the KIBS, which is particularly important in terms of its use of $3 \mathrm{D}$ printing. This category includes software development, design, and online platforms for the application of 3D printing (e.g., Ford, 2014; Rayna et al., 2015; Reeves and Mendis, 2015).

From our analysis of secondary data above, we were able to identify more than 25 firms as important exemplars of each of the industries included (Thomas, 2006). Factiva was the most useful source at this stage of the analysis, giving the most mentioned organisation in each industry, although where appropriate we also included organizations mentioned in other documents (Reeves and Mendis, 2015). These revealed some significant users of 3D printing (e.g., United States Government Accountability Office, 2015) that do not appear in newspaper articles. Having selected relevant firms we sought to supplement the emerging material by looking at information provided on the organization's website, as well as 3D printing focussed websites.

To provide more depth to our investigation we looked for examples of how different industries use 3D printing technologies in order to understand its impact on manufacturing firms and their ecosystems (Rayna et al., 2015). As there is currently little empirical evidence on the current state of 3D manufacturing ecosystems, our study took a broad view on how 3D technology is used and the different applications across different firms and industries. As with this type of work, data gathering and analysis ceased when no new themes emerged, suggesting that all the major themes had been captured (Marshall, 1999). From this analysis we were able to identify prototypical or illustrative examples of the application of 3D technologies within each of our four initial industry categories (Denzin and Lincoln, 2002) (Table 2). 


\section{INSERT TABLE 2 ABOUT HERE}

$\backslash$

An inductive approach (Patton, 1980) such as ours, also enables patterns, themes, and categories to emerge from the data rather than be placed in predetermined categories. In this paper these are: (1) the technological content of 3D printing and (2) the level of consumer involvement in the production process. We discuss these various categorisations in the following sections.

\section{Data analysis}

In the following section we discuss the use of 3D printing within each of the industry types developed above. This is to show how each style of competition has been used to exploit the potential of 3D printing technology. We also explore the strategies employed by the firms to develop or extend business models, in terms of the five dimensions of competitive dynamics as developed by Chen and Miller (2015).

\subsection{Supplier Dominated Firms}

Contexts we label as supplier-dominated see change coming from knowledge provided by suppliers. The suppliers work with firms that produce finished products at the final stage of the vertical chain (Castellacci, 2008; Pavitt, 1984) and these implement technologies developed outside the firm to improve their products and production process and do not invest heavily in all areas of R\&D. This is an example of Chen and Miller's mode of competing and action toolkit dimensions where position, knowledge and trajectory are significant (Chen and Miller, 2015). From our data, we found interesting examples in textile and wearing industries. Like Pavitt's industrial firms, the large apparel firms also invest strongly in R\&D (statista, 2015); smaller ones do not. Therefore, we focus on both designers and mass apparel manufacturers who are increasingly turning to $3 \mathrm{D}$ printing to produce low-volume, customized, and intricate goods as well as to reduce the costs of prototypes (United States Government Accountability Office, 2014).

There are benefits to using 3D printing technology for designers in both small shops, for example the Continuum fashion store, and haute couture, for example the designer Van Herpen who unveiled her 3D printed designs at Paris Fashion Week in 2013. In a similar way for industrial firms, 3D printing's CAD software enables designers to produce items without an expensive initial layout, and create easy personalization. In 2014 Japanese fashion designer Yuima Nakazato released a fashion collection that included 3D printed elements. As with other applications, current $3 \mathrm{D}$ often performs poorly against existing materials, and these fashion designs 
are not especially wearable and nor washable and so cannot be used in the broader market (Chabaud, 2016). 3D printing is also making in-roads into jewellery as well. American Pearl an American manufacturer of jewellery founded in 1950 has recently turned to 3D printing to compete with cheap overseas labour. Its CEO described the savings achieved as 'phenomenal'. But a second motivation was to empower consumers to make jewellery in real time (O'Connor 2014). 3D printing made it possible to design complicated geometries in a short time frame (Kaelin, 2013).

According to our data, 3D printing and automation technology is helping some footwear companies save money and time. Sporting goods firms like Nike and Adidas are using 3D printing to speed up the shoemaking process. For example, Adidas Group reduced the time it needed to evaluate a new prototype from four to six weeks to one or two days (Jopson, 2013). Shoemakers are also experimenting with 3D printing to accelerate personalization: it allows the manufacturer to do things that conventional shoemaking does not (Nike, 2014). Nike claimed that 3D printing enabled it to conceptualize the entire manufacturing ecosystem with the consumer at the center (Nike, 2015). This is an interesting development, as some of the earlier applications of 3D printing came from rapid prototyping, and these benefits are being exploited by current adopters working closely with their technology suppliers. The concern about the properties of the printed material is also one which has been expressed by industrial manufacturers and is one area where we see the suppliers having a crucial role. However, we found a significant issue with 3D technology resulting from the supplier-dominated side of the dynamic typology in that many firms complain about the restrictions arising from being tied to one printing supplier. They may not have the best materials or the most appropriate printing technology thus limiting the ultimate impact of the technology.

As the supplier firms develop better materials with properties allowing exploitation in more situations, we see the supplier dominated class becoming crucial for the development of workable business models, an area where there have been delays.

\subsection{Scale-Intensive Firms}

Scale-intensive industries include firms that invest internally in R\&D activities and develop close cooperation with specialized suppliers for their innovation activities. 3D printers are not currently used for mass production in this category, although the use of $3 \mathrm{D}$ printing for design and prototyping is growing. For a long time, the automotive industry has used $3 \mathrm{D}$ printing to make tool prototypes. Ford motor company, an early adopter of 3D printing, has been using the technology for prototypes since the 1980s (Ford, 2014). This has resulted in it reducing both time and cost. For example, a prototype intake manifold would take four months and $\$ 500,000$ using traditional methods, while with 3D printing, it takes four days and $\$ 3,000$ (Ford, 2013).

An additional benefit is in quality as seen at BMW, another early adopter of 
the technology, where 3D printed tools perform better than conventional ones (Grunewald, 2015). A third use is to manufacture components and spare parts which are no longer available on the open market (Earls and Baya, 2014). This brings alive Chen and Miller (2015) aims of competition and stresses the time horizon of interaction elements as relative competition start to become significant. An extreme example of the automobile industry is the case of KOR EcoLogic's Urbee car, 60 percent of which is manufactured using 3D printing (Ford, 2014). However, it is unlikely to see the use of $3 \mathrm{D}$ printing for mass production as the slow speed requires large numbers of machines to achieve high-volume production (Ford, 2013). It seems that the automotive industry will adopt the technology for direct manufacturing only when 3D printing can produce larger components (Ford, 2014).

Another problem with the scale-intensive model is that spare parts are a traditional way of recuperating the development costs for products ( $\mathrm{Li}$ et al., 2015). With the digitisation of spare parts, the barriers to prevent users from bypassing the supplier and producing the parts with another printer are weak. This has been seen as a concern for the firms to pursue 3D approaches.

The specific issues of scale on 3D printing have been examined by Holmström et al. (2016) where the critical cost focus of the manufacturing and supply network are severely hampered by the relatively long production times and solutions for these firms to adopt the technology for core activities is limited unless there are advances which significantly speed up production times.

\subsection{Science-Based firms}

Science-based industries rely on new technological knowledge for advances needed to operate in their markets and tend to generate it internally. They generally employ and engage in close collaborations with universities (Castellacci, 2008; Pavitt, 1984) one of the most important of the roster of actors identified in the competitive dynamics framework (Chen and Miller, 2015). In these settings, 3D has been shown to open up a new world of manufacturing for aerospace, defence, and advanced technologies. The aerospace industry requires parts that are strong, light and geometrically complex and 3D printing can reduce the amount of expensive material needed (Ford, 2014). The National Air and Space Administration (NASA) produced a rocket engine injector using $3 \mathrm{D}$ printing technologies, reducing costs and production time by $70 \%$ and $30 \%$ respectively (Boen, 2015). 3D printing has the ability to dramatically reduce the cost and cycle time of prototypes, tooling and production systems (Lockheed Martin, 2014).

Boeing already has more than 20,000 additively manufactured parts on its jet fleet. These components can easily be replaced with a 3D printer located anywhere in the world helping to improve cost structures and waiting times for both Boeing and its customers (Cole, 2004). Airbus is also increasingly focusing on 3D printing, exploiting many benefits including lighter parts, shorter lead times and less material waste (Airbus, 2016). General Electric, which the largest supplier of jet engines in the 
world, has produced light fuel nozzles for jet engines. These fuel nozzles combine what was previously welded from 21 separate parts (GE aviation, 2015).

The medical instruments and supplies industry create customized medical devices whilst the hearing aid industry uses the technology for manufacturing customized devices. Similarly, 3D printing has also been used for dental purposes. InvisAlign orthodontics, a well-known user of additive manufacturing, makes customized plastic aligners for teeth straightening (Ford, 2014). The pharmaceutical industry is also a leading user the technology. For example, Aprecia additively fabricated a pill, Spritam, the first drug by 3D printer the FDA approved. Patients may face administration and swallowing challenges. Spirtam allows the rapid disintegration of high-dose formulations. The company creates a single fast melting pill combining several ingredients. The tablet dissolves in less than four seconds making administering it much less stressful for patients (Mendoza, 2015).

3D printing holds significant potential for consumer electronics, as small audio firms can produce customised and short run premium products to allow the early adoption of new technologies. For example, Normal, produces customized, 3D printed earphones customised for each ear as even left and right ears can differ from each other by up to 20 percent (Naitove, 2015). Despite benefits of 3D printing, limits on the size of goods produced, issues with materials, and certification standards have constrained its adoption by some industries, including aerospace (Ford, 2014).

The issue we identified above concerning lock-in with certain suppliers is also pertinent here as the choice of supplier can potentially limit access to the science base for a firm as a result of their chosen partner. There can be barriers for a firm to access more appropriate technological solutions if these are developed by other firms, or they are already locked into relationships with competitors.

\section{$5.4 \quad$ Specialised suppliers}

This category includes knowledge intensive business services and industrial/business machines and material suppliers. As we have seen above, specialised suppliers can be found in the machinery and instrumental engineering category, and also in KIBS, which, include firms such as architects and design consultancies. Here, the supplier's role is one of support and knowledge transfer rather than production. Software often lies at the heart of their use of $3 \mathrm{D}$ printing as the process relies heavily on computer-aided design (CAD) software from suppliers such as Autodesk. New software from existing firms such as Google with their introduction of sketchup suggests that $3 \mathrm{D}$ is becoming a new, more mainstream, target market. KIBS users are often reliant on the expertise they get from the software suppliers or online platforms, which supply the design, and CAD modelling skills that they need (Elsworthy, 2015). In fact, it has been suggested that any increase in the use of $3 \mathrm{D}$ printing may be limited due to an insufficiently skilled workforce (United States Government Accountability Office, 2015).

An important element here within the KIBS is the development of open-source 
libraries providing 3D models to users. TurboSquid is a digital media company that sells stock 3D models to industries. It has the largest library of 3D models with more than 300,000 offers. Online platforms such as Sculpteo and i-materialise provide companies and designers with the facilities to sell 3D models of their products to customers (Rayna and Striukova, 2016). Online fabrication services can also provide on-demand 3D printing in small volumes. Customers upload a digital design and receive the $3 \mathrm{D}$ object within a few days.

Digitally open source manufacturing is allowing production processes to sometimes change from manufacturing-centric to user-centric. Rayna et al. (2015) list a number of design and manufacturing services now offered by $3 \mathrm{D}$ platforms including design crowdsourcing, in which a project is developed further by the crowd, product customisation in which third-party designs can be customised by users, and the printing and shipping to consumers or retailers of externally designed products. As von Hippel (2005, p.1) argues: " Users that innovate can develop exactly what they want, rather than relying on manufacturers... Moreover, individual users do not have to develop everything they need on their own: they can benefit from innovations developed and freely shared by others". This has become a powerful way of extending the design and innovation process away from a small number of (often large) innovative manufacturers to the interested individual designer/innovator. 3D printing extends the crowdsourcing paradigm not only to the ideation of the production process but also to the manufacturing stage (Rayna and Striukova, 2016). For example, Quirky, a consumer products design firms, turns crowd-sourced inventions into $3 \mathrm{D}$ products.

The KIBS area has received much coverage in the popular press, and are a distinct and contemporary addition to previous taxonomies. They epitomise a new type of competition that lie within the competitive dynamics model's recent identification of relativity and/or interdependence (Chen and Miller, 2015). It is in this area perhaps more than any other that 3D printing has had a radical effect, creating many new markets. The need for a new typology is compelling as a result.

\section{Discussion}

As we can see above, the interest concerning 3D printing is well founded as there are many firms exploring its potential. We see that digital technologies are slowly transforming the manufacturing process, but there is also much change in the manufacturing ecosystems formed around 3D printing (Rayna et al., 2015; Rayna and Striukova, 2016). As the technology matures, its use is likely to expand into the direct production of goods. However, for now it is only a few limited niches that are open to the different features that the technology offers and the use of 3D printing for the mainstream production of end use applications is a reality only for specific types of firms. 
The new taxonomy of sectoral patterns of 3D printing presented in Table 3 builds upon elements of previous sectoral classifications. However, previous classifications are incomplete where 3D printing is concerned: our new taxonomy now includes technological content, which determine the possible applications of 3D printing, and consumer involvement in the production process. It also includes a categorization of competitive dynamics between firms in the same industry and also across industries, reflecting the importance of relational competition and interdependence which are characteristic of 3D users' need for cooperation, even from rivals.

Many of the industry sectors that belong in the same sub-group of industry as we describe below have in common only similar levels of technological content. While firms in the supplier-dominated sector allow co-creation and personalisation in addition to their low technological content, firms in other sectors do not share similar features. The great variety of patterns between firms within the same sub-sector emphasizes the need for a new, more granular, taxonomy.

For traditional firms, as Conner et al. (2014) identify, production volume, customization, and complexity determines whether additive manufacturing is likely to provide an advantage over conventional manufacturing. We found no evidence that this was happening. However, supplier-dominated firms such as those in the apparel industry, jewellery, and footwear sectors, are using 3D printing to make products and to provide personalised. High volume makers such as Nike, choose to customise only limited editions whilst low volumes, such as in jewellery, enables 3D printing for the final product, also with personalisation.

In some industries 3D printing is not likely to replace conventional manufacturing, but will rather be an additional tool for manufacturers (United States Government Accountability Office, 2015). For our class of scale-intensive industries, 3D printing is mostly being used for specialised components and spare parts. Again, 3D printing has historically not been suitable for mass production as it is slow, uneconomical for mass-consumed products (Campbell et al., 2011), and the size of 3D printed objects has been limited to smaller components. As such, firms in industries such as automotives have found it difficult to adopt the technology widely (Ford, 2014).

3D printing has also found a niche application in technological industries with demanding structural and performance requirements. Parts such as automobile or jet engine components need to be reliably and consistently produced (United States Government Accountability Office, 2015). According to Ford (2014, p. 12) "issues with materials, accuracy, surface finish, and certification standards have further limited its use". A critical challenge for additive manufacturing in aerospace is the certification of finished parts and products (Defence IQ, 2016). In that respect it is worth noting that the FAA in 2015 approved the first 3D printed parts for commercial jet engines (GE Reports, 2015). Materials and processes for aerospace must be formally certified and requires thousands of tests, many years to complete, and at a significant cost. Re-qualifications are required for minor changes in the process 
(United States Government Accountability Office, 2015). Here the advantages of 3D printing and its rapid prototyping approach give benefits which may not always be exploited as a result.

In contrast with the aerospace industry, which is using the technology to develop only some components, the remaining firms within the science-based industry are advanced adopters of 3D printing end products. For example, the medical industry is using the technology to build customised products. The ability of $3 \mathrm{D}$ printing to produce low-volume, customized, and complex goods at a low cost makes its use ideal for the medical industry. However, the high technological content of the industry makes co-creation unlikely.

The evolution of 3D printing has led to the creation of new firms, which are providers of hardware and software as well as design consultancies. These are distinct from the production happening in the supplier-dominated class, and are to a large extent captured by Castellacci's Advanced Knowledge Providers. Ecosystem specialist suppliers need to provide firms with equipment and KIBS with knowledge services. These enabling tool firms have generated the most change in our sample as they are clearly dependent on new business models and are at the forefront of the sharing economy in a way that traditional production based organisations in Pavitt's types are not. In addition 3D printing technologies enable firms to produce on a smallscale, encouraging the development of start-ups. Aspiring entrepreneurs will no longer need the support of a manufacturer to produce their own ideas and individuals will be able to produce their own goods.

The last category we identify from our analysis are online platforms. These are a group within the Advanced Knowledge Providers and give the opportunity to firms, designers or individuals to collaborate in the production process. This is a formalisation of the maker economy and the development of online platforms show that consumers are interested in the personalisation and/or co-creation of products. 3D printing is enhancing the trend of open and user based innovation we have seen for several years.

3D printing enables consumers to intervene at any stage in the production process (Rayna et al., 2015). However, co-creation during the whole innovation process only happens in the case of supplier-dominated industries, design consultancies and online platforms. Empowerment of the so-called maker communities are thriving but up to a certain degree. The long tail of supply (Anderson, 2004) is valid only in a few industries. Industries which can use 3D printing for end products will have the greatest impact. They will have to adjust to the new era of co-creation and/or personalisation and will face competition from designers and new entrant firms as we see in KIBS and online platforms. In contrast, firms using 3D printing mainly for prototyping and tooling will see it have a limited impact, because the technology is placed within the traditional manufacturing process. Therefore, 3D printing will not replace conventional manufacturing for all industries, although it will have an effect on manufacturing ecosystem and value chain.

According to Schumpeter (1936) technological developments always result in 
high level of competitive activity and change the structure and competitive dynamics of an industrial ecosystem as new firms overthrow established ones. However, what the new ecosystem and industry looks like depends on many factors including how the technology affects competencies, and firms' incentives to invest in it (Sandström, 2016). 3D printing has significant implications for firms within industries with low level of technological content, as co-creation and consumer involvement is high, showing the value of the relative competition, relativity and interdependence dimensions at the heart of the most recent competitive dynamics frameworks (Chen and Miller, 2015). Supplier-dominated industries will face high competition from new entrants but also from specialist suppliers. Hardware and software firms enable individuals to produce their own products having a potential impact on the sales of supplier-dominated firms. Designers that were dependent on manufacturers may take manufacturing in their own hands (Rayna and Striukova, 2016).

As industry boundaries erode, firms are unexpectedly competing with unlikely rivals. Firms from previously adjacent industries are crossing industry borders resulting in intense competitive interactions. The dyadic relationship between a focal firm and its main rival is not sufficient for explaining the competitive behaviour of firms in a 3D world (Zucchini and Kretschmer, 2011), as stressed by historical competitive dynamics models with their reference to action/reaction dyads (e.g. Chen, 1996). Individuals also have the opportunity to open new firms, buy designs from online platforms or print objects locally. The dominant role of the consumer raises challenges for existing companies as it tends to face a 'crowd out' effect (Rayna and Striukova, 2010). Our taxonomy highlights the fundamental role of technological content and consumer involvement in the relative competition, relativity and interdependence dimensions of the competitive dynamics framework. First, sectors are divided according to their technological content. This allows the identification of groups of firms with low technological content and those with high technological content. These groups are subsequently divided into sectors on the basis of the level of consumer involvement. By using these two dimensions in our analysis we come up with five categories of firms: personalisation-dominated, singular science-dominated, customisation-dominated; collaborative science-dominated and intermediarydominated.

Personalisation-dominated firms are characterized by low technological content and a significant level of consumer empowerment. Supplier-dominated firms, including wearing apparel, jewellery and footwear belong to this category. These firms face intense competition from firms outside their own industry.

Singular science-dominated firms. These industries are characterized by a low level of consumer involvement. The industrial borders are clear and competitive dynamics across industrial sectors is non-existent. This category includes motor vehicles and aerospace industry. 
Customisation-dominated firms includes the medical, pharmaceutical, and electronics industries. Firms in this category are able to innovate internally. By producing personalised products with the help of 3D printing, this group of industrial sectors faces competition from new entrants but is not affected by convergence and competitive dynamics across industries.

Intermediary-dominated firms enable consumer involvement in the production process. Where they differ from personalisation-dominated firms is in terms of their technological capability and their ability to manage and create technological knowledge. Some KIBS are included in this category, the design consultancies and online platforms. This category intensifies the democratisation of manufacturing and convergence of industries.

Collaborative science-dominated firms constitute a key part of the new 3D printing ecosystem and enables the empowerment of individuals. They produce final goods that allow co-creation in other sectors. In contrast with previous taxonomies, specialised technology suppliers in the 3D printing ecosystem do not provide only intermediary products but also products for end users, increasing competitive tensions with other industries. In terms of their technological content, they are characterized by their significant innovation capacity. This category includes 3D printing materials and equipment and software suppliers. 


\section{INSERT TABLE 3 ABOUT HERE}

Our typology provides a comprehensive framework that accounts for the transformations that occur with the emergence of $3 \mathrm{D}$ printing technologies. The taxonomic model suggests that the development of 3D printing technologies has brought significant changes in the division of industrial sectors. Today's consumers expect personalised experiences, and they are increasingly willing to contribute to product development. As demonstrated through our five-group typology each industry must adapt to how consumers can access products in new ways.

Our study also shows that in the current era of digitalisation, firms are less likely to engage in a purely rivalrous form of competition but are more likely to be engaged in a relational or hybrid type of competition, and in this way we additionally contribute to the competitive dynamics literature. Particularly, we have shown that the evolution of the fourth industrial revolution needs dynamic alliances that are being mingled together into a complex ecosystem for the mutual survival and common benefits of the various players. In support of Chen and Miller's (2015) proposition that firms in industries that are nascent or in crisis tend to engage in relational competition, we found that for the successful evolution of 3D printing there needs to be co-development of materials, computer software and 3D printers, all of which are being invented or refined and developed in parallel (Kapetaniou and Rieple, 2017).

3D ecosystem participants have to deal with uncertainties resulting from unknown components in terms of technical feasibility, functionality or qualities that allow them to be combined to create a new solution (Dyer et al., 2014). In addition, the digital age is fundamentally reshaping the structure of firms and industries by combining multiple, previously disparate product systems and industries. Partners which come from radically different industries and organisations, including consumer electronics, online retailing, customers, universities and government agents, are now forming dynamic alliances that enable each participant to thrive.

\section{Application to the competitive dynamics model}

Despite the prevalence of the relational perspective in the current evolution of automation technologies our findings suggest that it varies according to industry sector. Although the aim of relational competitive dynamics is to lift multiple boats, and the goal is a win-win exchange, we suggest that the cooperative partners in each sector differs, and through using the AMC (Awareness-Motivation-Capability) model of Chen and Miller (2012), in the following section we map our typology of 3D-based industries against the way that they engage in relational competition. The AMC framework allows us to merge our typology with recent theorising on competitive dynamics to identify the different types of cooperative partners (roster of actors), modes, aims and time horizons of competition, and their action toolkits in the 
category of relational competitive dynamics. This categorisation further allows us to explore how relational competitive dynamics are starting to change as traditional industry boundaries disappear. Within our framework the choice of competition is driven contingently by actors' awareness, motivation and capabilities, mitigated by the industry's characteristics.

\section{Type I: Singular Science-, Customisation- and Collaborative Science-dominated}

We argue that the Science-Dominated, Singular Science-Dominated, and Customisation-Dominated industries, due to their higher levels of relational awareness, motivation, and capabilities, are more likely to engage in purely relational competition. Firms in these categories are characterised by high absorptive capacity, which allows them to be more aware of one another's strengths and weaknesses, identify new technological opportunities and create new relationships with other actors (Cohen and Levinthal, 1989; Link and Bauer, 1987). The motivation for the relational mode is to develop innovation, which in these industries is highly complex and long-term increasing the need for interconnectedness in order to make accessible any necessary, but previously unknown, resources (Kapetaniou and Rieple, 2017). There is a scarcity of resources and there is an incentive for firms and institutions to collaborate within and across ecosystems to stimulate widespread innovation. They embrace a range of parties that are relevant not merely to an organization's success, but to the well-being of many organisations and institutions that would be affected by the new technology. Cooperative partners include public institutions such as universities that might be funded to engage in $R \& D$ activities, firms within the same industry to contribute to the development of standards and infrastructure, national authority agencies to improve the safety of materials, suppliers to improve the quality of products, and employees to improve skills relevant for efficient use and maintenance of the new equipment. The technological capability of firms in high-tech industries requires an ability to manage relationships with multiple actors, assimilate knowledge spillovers (Rosenkopf and Nerkar, 2001) and transform the fundamental knowledge supplied by various partners into commercial success. In this context, their high technological capabilities is a prerequisite to attract competent technical staff and collaboration partners (Dahlander and Gann, 2010), and needs to be accompanied by capabilities in the awareness and selection of appropriate partners.

\section{Type II Personalisation-dominated}

We suggest that firms in the Personalisation-Dominated category also engage in relational competition due to their high levels of relational awareness, motivation, and capability. These types of firms are recipients of goods, services and knowledge produced in other industries. As discussed before, these firms are at the final stage of the vertical chain and are often characterized by a low technological content and short 
time horizons. Their mode of competition, which in the past was typically based on the acquisition of machinery and equipment produced by their suppliers, is nowadays also based on high consumer involvement in the product development process. This is in an era where the democratisation of manufacturing and the number of prosumers is on the rise. Their strong online presence, which underpins co-creation, plays a critical role in enhancing awareness of opportunities for relational conduct. Thus Web 2.0 technologies provide the means for firms to form strategic alliances with key stakeholders, both virtually and interpersonally proximate. The motivation for the relational mode is to collaborate with competitors in related industries such as online platforms and clients which can provide access to the key resources that enable the firm to facilitate co-creation activities. Knowledge partners and users are freely available therefore firms need to develop capabilities in selecting and forming relationships in order to co-develop products.

\section{Type III: Intermediary-dominated}

The Intermediary-Dominated industries intensify the democratisation of manufacturing and enable production processes to change from manufacturing-centric to user-centric. Online platforms and digital designers have introduced a new way for communicating between users, while providing new opportunities for doing business. They represent the supporting base upon which co-creation activities in other sectors can be built, and they continuously upgrade and renew it. The scope of possible interaction partners include suppliers of factors of co-creation such as firms that are often indirect rivals and individuals that may become parties to alliances, as well as public authorities who can tackle impending intellectual property (IP) issues. They combine characteristics of both type I and type II relational competitive dynamics. Using their high absorptive capacity and online presence allows them to become aware of threats from rivals, including individuals or personalization-dominated industries, as well as their potential for collaboration. The motivation is for the firm's product/service to serve as the foundation upon which other actors come together to build their own designs or products. This may be in a synchronous relationship, or can be asynchronous as the platform allows users to interact with the product of the firm without direct interaction with the firm itself. As more users register in the platform or collaborate with a designer, the more valuable their services become. Their online presence enable them to pursue modes of competition that allow them to identify users and at the same time continual improvements and innovations allow them to improve their services and attract diverse users and potential collaborators.

\section{Conclusion and implications}

The purpose of this paper was to understand how 3D printing technologies 
have changed the competitive landscape for firms that employ this technology. Based on a systematic review of firms which are users of 3D printing we have developed a new, extended and updated, taxonomy of industry types that facilitates an understanding of how 3D printing has changed the dynamics of competition, product development processes, and sources of competitive advantage in different manufacturing and service sectors. The new taxonomy of sectoral patterns builds upon and combines technological capabilities of firms, an element of previous sectoral classifications, with consumer involvement in the production process as well as incorporating the differences in competition/cooperation, particularly across industries as represented in competitive dynamics' models. The new taxonomy consists of five sectors; personalisation-dominated firms, intermediary-dominated firms, collaborative science-dominated firms, customisation-dominated firms and singular science-dominated, each representing different mixes and stresses on the five fundamental dimensions of the competitive dynamics framework: aims of competition, mode of competing, roster of actors, action toolkit and the time horizon of interaction.

Our study shows that the use of 3D printing for direct manufacturing influences the level of disruption in different industries. Including KIBS in our model, we are able to explore the impact of 3D printing technology in wider areas than just traditional manufacturing. We noticed the major difference between using 3D printing as a production system or as an enabling technology for others in more recently evolved knowledge rich industries. The intermediary-dominated firms and collaborative science-dominated firms lead development by providing tools and modelling systems which allow firms and individuals to exploit their abilities in new areas or more effectively in existing ones. These firms accelerate the do-it-yourself inventing and making (Anderson, 2012).

Sandström (2011) argues that technological developments can result in competitive turbulence and overthrow dominant firms and industries. Susson (2013, p.43) claims that "3D printing is not likely to replace traditional manufacturing methods for most applications - it simply takes too long to print individual objects to make it cost effective on a sufficiently large scale". Our work shows that the level of use of 3D printing for end products, is defining the impact of the technology on the various types of manufacturing firms.

Our study provides a detailed understanding of the level of user involvement in production and the nature of co-creative processes. The level of direct manufacturing and consumer empowerment in each industry will determine the competitive dynamics. Firms which are able to replace conventional manufacturing with 3D printing will have to respond to the impact of technological advances on their sector by introducing customers in the production process. The paper shows that $3 \mathrm{D}$ printing will enable the monetising of the 'long tail' (Anderson, 2008) but only in specific industries, and particularly in personalisation-dominated firms and customisation-dominated firms.

The taxonomic model suggests that the development of $3 \mathrm{D}$ printing 
technologies has brought significant changes in the division of industrial sectors. The existence of a web of vertical linkages among industries and the specialization of activities in each sector of previous industrial taxonomies is no longer valid. The accessibility of the technology to individuals who are able to fill more of their demands themselves and the participation of customers in the production process is changing the way sectors compete, blurring the boundaries of some industries.

Our study has practical implications. Most firms in most industries will be faced with the need to implement 3D printing technologies to a greater or lesser extent. Firms can locate their industry on the map and begin the process of creating specific strategies for competitive advantage. Some industries, such as singular science-dominated firms, which do not use 3D printing for end products, have financial incentives to adopt the new technology for other applications such as pilot run and the production of specific components. In industries which firms are able to use 3D printing for direct manufacturing of end products, for example personalisation-dominated firms, face intense competitive activity across intermediaries and collaborative science-dominated firms as industry boundaries are becoming less clear. Customers no longer receive value through the purchase of mass customised products. Instead, they interact with firms and online communities in order to have a product that is personalised. 3D printing will provide opportunities for new firms and individuals who can become manufacturers, leading to a crowding-out effect for existing companies. Therefore, firms within industries that allow cocreation and personalisation need to fundamentally alter their value creation infrastructures. Collaborative science-dominated firms need to focus not only on innovators in their industries but also on individuals who would like to produce their own goods and/or start new firms.

$3 \mathrm{D}$ printing has been tipped as a prospective game-changer and the ability to produce and deliver small quantities, tailor made and complex products more flexibly and rapidly for local customers allows new value creation and business opportunities. That is not to say that all types of manufacturing will be replaced - those that require 'traditional' scaled mass production may benefit less from 3D technologies than others. 3D printing also remains beset by technological issues, including a lack of design skills and material quality issues. Making an object does not only require hardware and software but also advanced knowledge of 3D modelling (CAD) software. Design was previously determined by contextual factors including the size of organisations and its engagement in R\&D activity (Roper et al., 2016). However, in the digital world of 3D printing design is fundamental for all organisations. Government policies should support the development of design competencies to enable firms to access appropriate design resources (Roper et al. 2016). Moreover, they need to ensure that firms are aware of the advantages of $3 \mathrm{D}$ printing, and promote funding strategies (TEKES, 2015).

Our results suggest areas for future research not least because of the way we gathered our data demanding a more complete future analysis of the evidence. First, this research has only looked at the $3 \mathrm{D}$ printing technology impact on industrial 
taxonomy, and we feel that other digital transformation technologies such as Internet of things or robotics technologies may be able to use the taxonomy. Second, while our findings highlight the impact of 3D printing in different industries using secondary data, there is a need for more in-depth qualitative research. A case study focusing on a particular industry to get more in-depth data for that industry is necessary. Lastly, further research is necessary to understand the relation between national context and 3D printing, and particularly on how countries at different stages on industrial development might exploit different routes to exploit the technology. Different country cases should be analysed to compare the different tactics they use. Such an approach may be useful in more fully understanding the role of innovation policies in the promotion of radical technologies (Kapetaniou and Lee, 2016).

In conclusion we feel that by capturing such a wide range of evidence on how 3D printing is being used allowed us to develop a typology capable of explaining the many areas the technology can impact. Academics can use the typology to plot and build understanding of the mechanisms at work, whilst firms can explore the wider potential of the technology away from just as a direct replacement for existing production processes.

\section{References}

Airbus (2016). Innovative 3D printing solutions are "taking shape" within Airbus.

[Online]. Available: http://www.airbus.com/newsevents/news-eventssingle/detail/innovative-3d-printing-solutions-are-taking-shape-within-airbus/ [Accessed: 13-Feb-2016].

Anderson, C. (2004). The long tail. Wired, 12 (10).

Anderson, C. (2008). Long tail, the, revised and updated edition: Why the future of business is selling less of more. New York: Hyperion Books.

Anderson, C. (2012). Makers: The new industrial revolution. New York: Crown Business.

Archibugi, D. (2001). Pavitt's taxonomy sixteen years on: a review article. Economics of Innovation and New Technology, 10(5), 415-425.

Baden-Fuller, C., and Haefliger, S. (2013). Business models and technological innovation. Long Range Planning, 46(6), 419-426.

Berman, B. (2012). 3D printing: The new industrial revolution. Business Horizons, 55(2), 155-162.

Boen, B. (2015). Rocket engine injector manufactured with 3D printing machine. [Online]. Available: 
https://www.nasa.gov/exploration/systems/sls/multimedia/gallery/3d_printer_2.html [Accessed: 25-Feb-2016].

Bogers, M., Hadar, R., and Bilberg, A. (2016). Additive manufacturing for consumercentric business models: Implications for supply chains in consumer goods manufacturing. Technological Forecasting and Social Change, 102, 225-239.

Brooks, G., Kinsley, K., and Owens, T. (2014). 3D printing as a consumer technology business model. International Journal of Management and Information Systems, 18(4), 271.

Campbell, T., Williams, C., Ivanova, O., and Garrett, B. (2011). Could 3D printing change the world? Technologies, potential, and implications of additive manufacturing. Washington DC: Atlantic Council. [Online]. Available http://www.atlanticcouncil.org/publications/reports/could-3d-printing-change-theworld [Accessed: 25-Feb-2016].

Castellacci, F. (2008). Technological paradigms, regimes and trajectories: Manufacturing and service industries in a new taxonomy of sectoral patterns of innovation. Research Policy, 37(6), 978-994.

Chabaud, C. (2016). 3D printed clothes: Fashion designers create wearable garments. [Online]. Available: https://www.sculpteo.com/blog/2016/01/27/making-wearable-3dprinted-clothes/ [Accessed: 10-Jun-2016].

Chen, M. J. (1996). Competitor analysis and interfirm rivalry: Toward a theoretical integration. Academy of Management Review, 21(1), 100-134.

Chen, M. J., and Miller, D. (2012). Competitive dynamics: Themes, trends, and a prospective research platform. The Academy of Management Annals, 6(1), 135-210.

Chen, M. J., and Miller, D. (2015). Reconceptualizing competitive dynamics: A multidimensional framework. Strategic Management Journal, 36(5), 758-775.

Christensen, C. M. (1997). The innovator's dilemma. Boston: Harvard Business School Press.

Christensen, C. M., and Raynor, M. E. (2003). Why hard-nosed executives should care about management theory. Harvard Business Review, 81(9), 66-75.

Cohen, W. M., and Levinthal, D. A. (1989). Innovation and learning: the two faces of R\&D. The Economic Journal, 99(397), 569-596.

Cole, W. (2004). Boeing engineers and technologists are constantly developing better ways to design and make products. [Online]. Available: 
http://www.boeing.com/news/frontiers/archive/2004/december/ts_sf03.html [Accessed: 01-May-2016].

Conner, B. P., Manogharan, G. P., Martof, A. N., Rodomsky, L. M., Rodomsky, C. M., Jordan, D. C., and Limperos, J. W. (2014). Making sense of 3D printing: Creating a map of additive manufacturing products and services. Additive Manufacturing, 1 , 64-76.

Cotteleer et al. (2014). 3D Opportunity in Tooling [Online]. Available: $\mathrm{http}$ //dupress.com/articles/additive-manufacturing-3d-opportunity-in-tooling/ [Accessed: 15-May-2016].

Dahlander, L., and Gann, D. M. (2010). How open is innovation?. Research policy, 39(6), 699-709.

De Jong, J. P., and de Bruijn, E. (2013). Innovation lessons from 3-D printing. MIT Sloan Management Review, 54(2), 43.

Defence IQ (2016). Additive Manufacturing in Aerospace, Defence \& Space Trends and Analysis 2016. [Online]. Available:

https://defencesummits.files.wordpress.com/2016/02/additive-manufacturing-indefence-and-aerospace-analysis-and-trends-20161.pdf [Accessed: 22-May-2016].

Denzin, N. K., and Lincoln, Y. S. (2002). The qualitative inquiry reader. CA: Sage.

Downes, L., and Nunes, P. (2013). The big idea: Big-bang disruption. Harvard Business Review, 1-12.

Earls, A., and Vinod B. (2014). Software innovations: Simplifying the 3Dexpirience.[Online]. Available: http://www.pwc.com/us/en/technologyforecast/2014/3d-printing/features/3d-printing-innovation.html [Accessed: 15-Apr2016].

Elsworthy, C. (2015). The disconnect between 3D printing software \& hardware. [Online] https://3dprint.com/47718/3d-printer-hardware-software/ [Accessed: 20-Feb2016].

Evangelista, R. (2000). Sectoral patterns of technological change in services.

Economics of Innovation and New Technology, 9(3), 183-222.

Firat, A. F., and Venkatesh, A. (1995). Liberatory postmodernism and the reenchantment of consumption. Journal of Consumer Research, 22 (3), 239-267.

Ford (2013). Ford's 3D-Printed Auto Parts Save Millions, Boost Quality. [Online]. Available: 
https://media.ford.com/content/fordmedia/fna/us/en/news/2013/12/12/ford_s-3dprinted-auto-parts-save-millions--boost-quality.html [Accessed: 15-Feb-2015].

Ford, S. (2014). Additive Manufacturing Technology: Potential Implications for U.S. Manufacturing. Journal of International Commerce and Economics. [Online].

Available:

http://www.usitc.gov/publications/332/journals/vol_vi_article4_additive_manufacturi ng_technology.pdf [Accessed: 10-Mar -2016].

Ford, S., Mortara, L., and Minshall, T. (2016). The emergence of additive manufacturing: introduction to the special issue. Technological Forecasting and Social Change, 102, 156-159.

GE aviation (2015). Additive manufacturing building the future... One layer at a time. [Online]. Available: http://www.geaviation.com/company/additivemanufacturing.html [Accessed: 15-Feb-2016].

GE Reports (2015). The FAA Cleared The First 3D Printed Part To Fly In A Commercial Jet Engine From GE. [Online]. Available:

http://www.gereports.com/post/118394013625/these- engineers-3d-printed-a-mini-jetengine-then, [Accessed: 26-May-2015].

Ghemawat, P., and Cassiman, B. (2007). Introduction to the special issue on strategic dynamics. Management Science, 53(4), 529-536.

Gimeno, J., Chen, M. J., and Bae, J. (2006). Dynamics of competitive repositioning: A multidimensional approach. Advances in Strategic Management, 23(1), 399-444.

Grunewald (2015). BMW celebrates 25 years of using 3D printing technology to build cars. [Online]. Available: https://3dprint.com/106539/bmw-25-years-of-3d-tech/ [Accessed: 10-Mar-2016].

Grynol, B. (2013). Disruptive Manufacturing - The effects of 3D Printing. Quebec: Deloitte LLP.

Henderson, R. M., and Clark, K. B. (1990). Architectural innovation: The reconfiguration of existing product technologies and the failure of established firms. Administrative Science Quarterly, 35(1), 9-30.

Hewitt-Dundas, N. (2006). Resource and capability constraints to innovation in small and large plants. Small Business Economics, 26(3), 257-277.

Holmström, J., Hollweg, M., Khajavi, S., and Partanen, J, (2016). The direct digital manufacturing (r)evolution: definition of a research agenda, Operations Management Research, 9(1), 1-10. 
Howe, J. (2006). The rise of crowdsourcing. Wired Magazine, 14(6), 1-4.

Jia, F., Wang, X., Mustafee, N., and Hao, L. (2016). Investigating the feasibility of supply chain-centric business models in 3D chocolate printing: A simulation study. Technological Forecasting and Social Change, 102, 202-213.

Jopson, B. (2013). New stamping ground for Nike and Adidas as 3D shoes kick off.[Online]. Available: http://www.ft.com/intl/cms/s/0/1d09a66e-d097-11e2- a05000144feab7de.html\#axzz3DnniBpns/ [Accessed: 13-Feb-2016].

Kaelin (2013). Yuima Nakazato releases new 3D printed fashion collection. [Online]. Available: http://www.3dprinterworld.com/article/yuima-nakazato-releases-new-3dprinted-fashion-collection [Accessed: 10-Mar-2016].

Kapetaniou, C., and Lee, S. H. (2016). A framework for assessing the performance of universities: The case of Cyprus. Technological Forecasting and Social Change. (doi:https://doi.org/10.1016/j.techfore.2016.03.015).

Kapetaniou, C., and Rieple, A. (2017, January). The role of business ecosystems in the building of disruptive innovations. In Academy of Management Proceedings (Vol. 2017, No. 1, p. 15200). Academy of Management.

Lewin, A.Y., and Massini, S. (2003). Knowledge Creation and Organizational Capabilities of Innovating and Imitating Firms. In H. Tsoukas and N. Mylonopoulos (Eds.), Organizations as Knowledge Systems (pp. 209-237). Hampshire: Palgrave.

Li, Y., Jia, G., Cheng, Y., and Hu, Y. (2017). Additive manufacturing technology in spare parts supply chain: a comparative study. International Journal of Production Research, 55(5), 1498-1515.

Link, A. N., and Bauer, L. L. (1987). An economic analysis of cooperative research. Technovation, 6(4), 247-260.

Lockheed Martin (2014). Additive Manufacturing and a New Revolution in Design Engineering. [Online]. Available:

http://www.lockheedmartin.co.uk/us/news/features/2014/additive-manufacturing.html [Accessed: 20-Feb-2016].

Manyika, J., Chui, M., Bughin, J., Dobbs, R., Bisson, P., and Marrs, A. (2013).

Disruptive technologies: Advances that will transform life, business, and the global economy. New York: McKinsey Global Institute.

Marshall, M. N. (1999). Improving quality in general practice: qualitative case study of barriers faced by health authorities. British Medical Journal, 319(7203), 164-167. 
Mendoza, H. R. (2015). Aprecia's 3D printed zipdose tablets earn FDA approval. [Online]. Available: https://3dprint.com/86534/3d-printed-zipdose-fda/ [Accessed: 13-Feb-2016].

Miles, I. (1993). Services in the new industrial economy. Futures, 25(6), 653-672.

Miozzo, M., and Soete, L. (2001). Internationalization of services: a technological perspective. Technological Forecasting and Social Change, 67(2), 159-185.

Naitove (2015). Additive manufacturing is the new normal [Online]. Available: $\mathrm{http} / /$ www.additivemanufacturing.media/articles/additive-manufacturing-is-the-newnormal(2) [Accessed: 15-Mar-2016].

Nike (2014). FY 2014 Q3 earnings release conference call transcript. [Online]. Available:

http://www.sec.gov/Archives/edgar/data/32018[7/000032018714000023/a8kq3fy14erccexhibit991.htm [Accessed: 20-Feb-2016).

Nike (2015). Nike Investor Meeting. [Online]. Available: http://s1.q4cdn.com/806093406/files/events/Documents/Eric-Sprunk_FinalTranscript-with-images.pdf [Accessed: 20-Feb-2016].

O' Connor, C. (2014). How a jewelry company is making $\$ 250,000$ pieces using $3 \mathrm{~d}$ printing and google earth. [Online].

http://www.forbes.com/sites/clareoconnor/2014/02/28/how-a-jewelry-company-ismaking-250000-pieces-using-3d-printing-and-google-earth/\#7ef1 131 ded7b [Accessed: 15-May-2016].

Patton, M. Q. (1980). Qualitative evaluation methods. Beverly Hills.

Pavitt, K. (1984). Sectoral patterns of technical change: towards a taxonomy and a theory. Research Policy, 13(6), 343-373.

Pavitt, K. (1998). Technologies, products and organization in the innovating firm: what Adam Smith tells us and Joseph Schumpeter doesn't. Industrial and Corporate Change, 7(3), 433-452.

Petrick, I. J., and Simpson, T. W. (2013). 3D printing disrupts manufacturing: how economies of one create new rules of competition. Research-Technology Management, 56(6), 12-16.

Petrovic, V., Vicente Haro Gonzalez, J., Jorda Ferrando, O., Delgado Gordillo, J., Ramon Blasco Puchades, J., and Portoles Grinan, L. (2011). Additive layered manufacturing: sectors of industrial application shown through case studies. International Journal of Production Research, 49(4), 1061-1079. 
Piller, F. T., Weller, C., and Kleer, R. (2015). Business Models with Additive Manufacturing-Opportunities and Challenges from the Perspective of Economics and Management. In C. Brecher (Ed.), Advances in Production Technology (pp. 3948). Cham: Springer International Publishing.

Prahalad, C. K., and Ramaswamy, V. (2004). Co-creation experiences: The next practice in value creation. Journal of Interactive Marketing, 18(3), 5-14.

Rayna, T., and Striukova, L. (2015). Open innovation 2.0: is co-creation the ultimate challenge?. International Journal of Technology Management, 69(1), 38-53.

Rayna, T., and Striukova, L. (2010). Large-scale open innovation: open source vs. patent pools. International Journal of Technology Management, 52(3/4), 477-496.

Rayna, T., and Striukova, L. (2016). From rapid prototyping to home fabrication: How 3D printing is changing business model innovation. Technological Forecasting and Social Change, 102, 214-224.

Rayna, T., Striukova, L., and Darlington, J. (2015). Co-creation and user innovation: The role of online 3D printing platforms. Journal of Engineering and Technology Management, 37, 90-102.

Reeves, P., and Mendis, D. (2015). The current status and impact of 3D printing within the industrial sector: an analysis of six case studies. London: UK Intellectual Property Office.

Ritzer, G., and Jurgenson, N. (2010). Production, Consumption, Prosumption The nature of capitalism in the age of the digital 'prosumer'. Journal of Consumer Culture, 10(1), 13-36.

Roper, S., Micheli, P., Love, J. H., and Vahter, P. (2016). The roles and effectiveness of design in new product development: A study of Irish manufacturers. Research Policy, 45(1), 319-329.

Rosenkopf, L., and Nerkar, A. (2001). Beyond local search: boundary-spanning, exploration, and impact in the optical disk industry. Strategic Management Journal, 22(4), 287-306.

Royal Academy of Engineering (2014). Additive manufacturing: Opportunities and constraints. [Online]. Available:

http://www.raeng.org.uk/publications/reports/additive-manufacturing. [Accessed: 30Feb-2016]. 
Sandström, C. (2011). Hasselblad and the shift to digital imaging. IEEE Annals of the History of Computing, 33(3), 55-66.

Sandström, C. (2016). The non-disruptive emergence of an ecosystem for 3D Printing-Insights from the hearing aid industry's transition 1989-2008.

Technological Forecasting and Social Change, 102, 160-168.

Schmidt, G. M., and Druehl, C. T. (2008). When is a disruptive innovation disruptive?. Journal of Product Innovation Management, 25(4), 347-369.

Schumpeter, J. A. (1936). Review of Keynes's general theory. Journal of the American Statistical Association, 31, 791-795.

Schumpeter, J. A. (1939). Business Cycles. New York: McGraw-Hill.

Schumpeter, J.A. (1942). Capitalism,Socialism and Democracy. New York: Harper \& Row.

Standard, A. S. T. M. (2012). Standard terminology for additive manufacturing technologies. West Conshohocken, PA: ASTM International.

Statista (2015). Ranking of the 20 companies with the highest spending on research and development in 2015 (in billion U.S. dollars). [Online]. Available: http:/www.statista.com/statistics/265645/ranking-of-the-20-companies-with-thehighest-spending-on-research-and-development/ [Accessed: 25-May-2015].

Susson, M. A. (2013). Watch the world "burn": Copyright, micropatent and the emergence of 3D printing. Social Science Research Network. [Online]. Available: http://ssrn.com/abstract=2253109 [Accessed: 30-May-2016].

TEKES (2015). Policy Brief: 3D Printing for Industrial Innovation. [Online]. Available: https://www.tekes.fi/globalassets/global/ohjelmat-japalvelut/kampanjat/innovaatiotutkimus/policybrief_6_2015_admani.pdf [Accessed: 25-Feb-2015].

Thomas, D. R. (2006). A general inductive approach for analyzing qualitative evaluation data. American Journal of Evaluation, 27(2), 237-246.

United States Government Accountability Office (2015). 3D Printing: Opportunities, challenges and policy implications of additive manufacturing. [Online]. Available: http://www.gao.gov/assets/680/670960.pdf [Accessed: 10-Apr-2016].

Von Hippel, E., (2005). Democratizing innovation: The evolving phenomenon of user innovation. Journal für Betriebswirtschaft, 55(1), 63-78.

Wohlers T. (2012). Additive Manufacturing and 3D Printing State of the Industry. 
Annual Worldwide Progress Report. Colorado: Wohlers Associates.

Wohlers, T. (2014). Tracking Global Growth in Industrial-Scale Additive Manufacturing. 3D Printing and Additive Manufacturing, 1(1), 2-3.

Wohlers (2017). Wohlers Report. Colorado: Wohlers Associates. [Online]. Available: http://www.cadalyst.com/hardware/3d-printers/wohlers-report-findsslower-overall-growth-more-competition-3d-printing-space-3 [Accessed: 17-Aug2017].

Zucchini, L., and Kretschmer, T. (2011). Competitive pressure: Competitive dynamics as reactions to multiple rivals, paper presented at Annual Meeting of the Academy of Management, St. Antonio, Texas. 

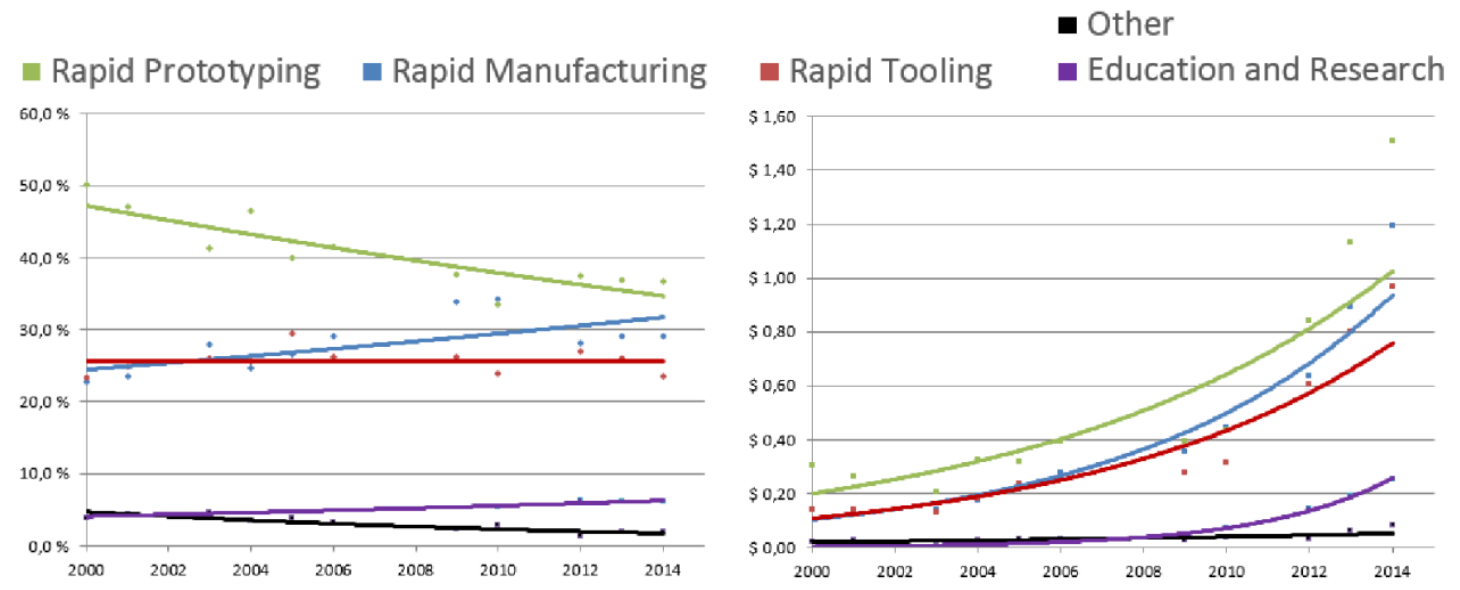

\section{Figure 1.}

Percentage of usage of the technology per application and revenue in US\$ billion per industrial application (Source: Wohlers 2000 to 2014 adapted in TEKES 2015 - Teknologian Kehittämiskeskus [the Finnish Funding Agency for Technology and Innovation]) 


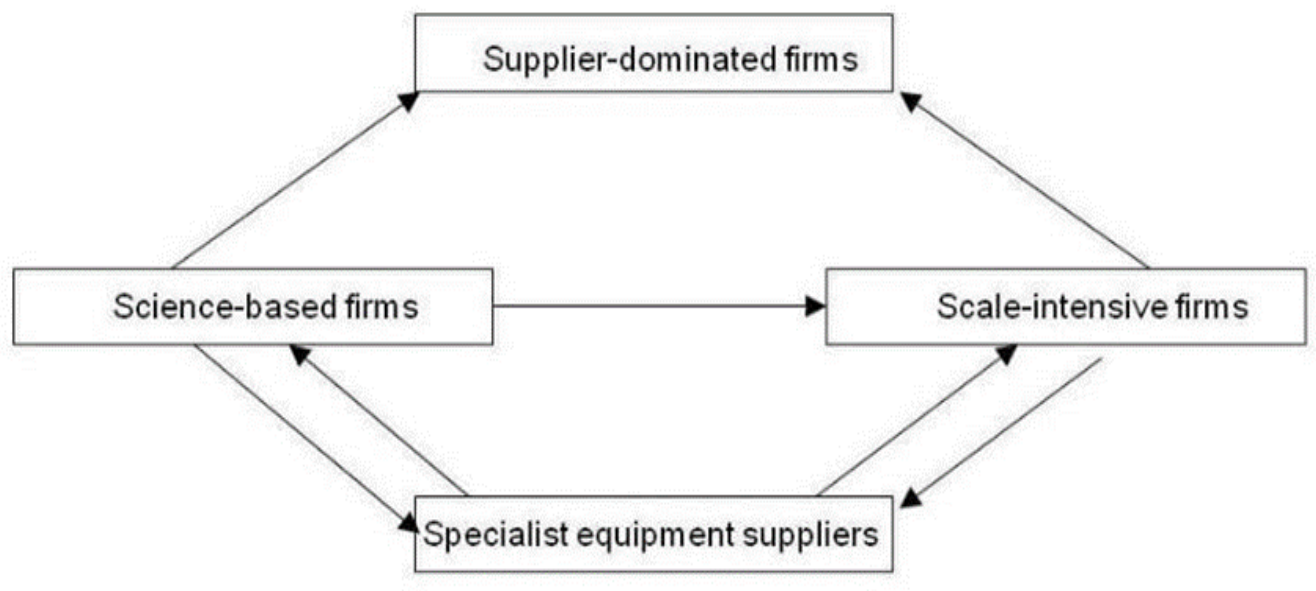

Figure 2.

The main technological linkages among different groups of industrial sectors (Source: Pavitt 1984, p.364). 


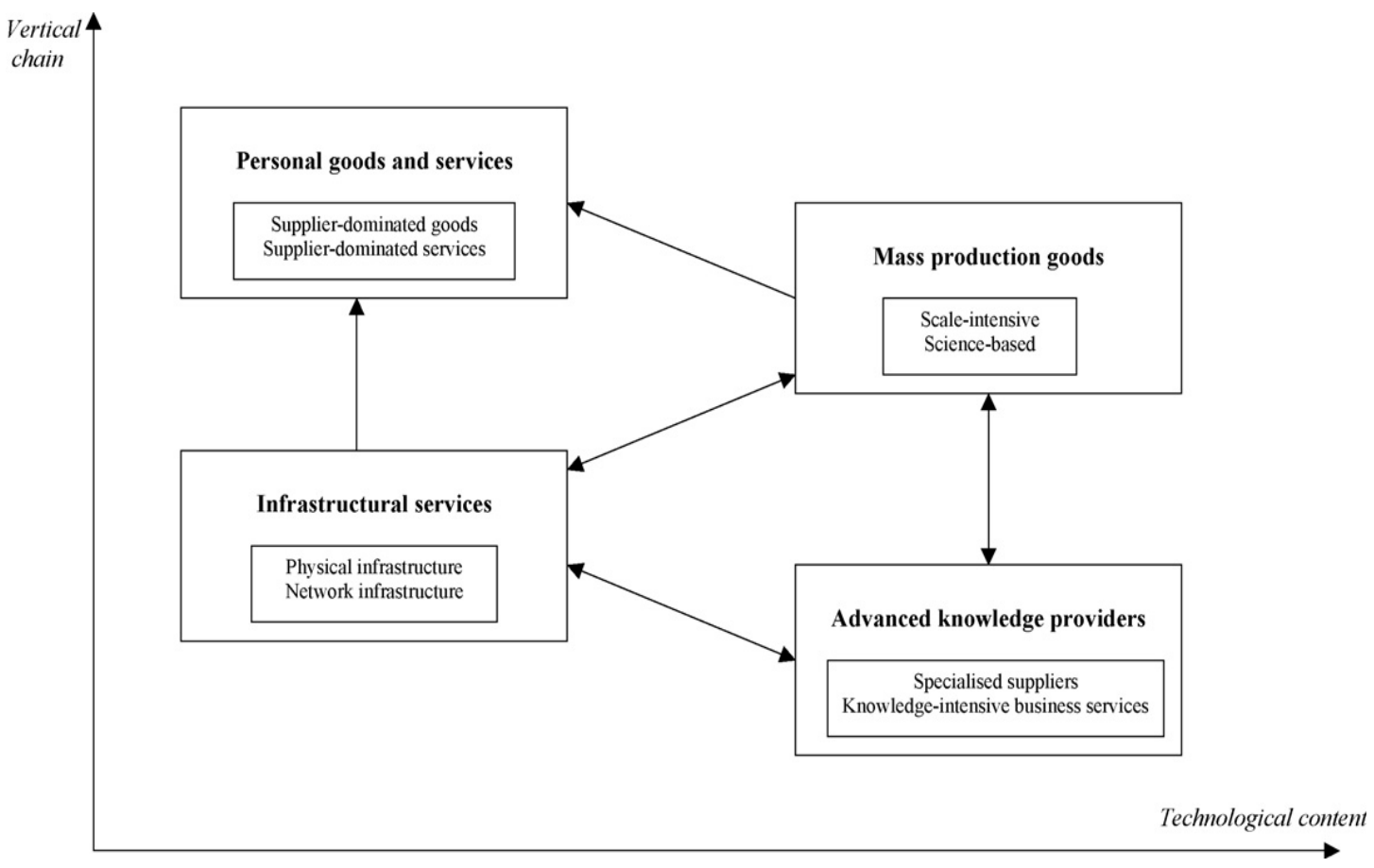

Figure 3.

A taxonomy of sectoral patterns of innovation in manufacturing and service industries (Source: Castellacci 2008, p.983) 


\section{Table 1.}

Leading implementers of 3D printing technologies (Source: Wohlers Report 2017 adapted by the authors)

\begin{tabular}{ll}
\hline Industry & Relative \% use of 3D printing \\
\hline Industrial/Business machines & $19 \%$ \\
Aerospace & $18 \%$ \\
Motor vehicles & $15 \%$ \\
Consumer products/Electronics & $13 \%$ \\
Medical/Dental & $11 \%$ \\
Academic Institutions & $8 \%$ \\
Other & $7 \%$ \\
Government/Military & $6 \%$ \\
Architectural & $3 \%$ \\
Total & $100 \%$ \\
\hline
\end{tabular}


Table 2. Firms used in our initial analysis

\begin{tabular}{|c|c|c|}
\hline Sector Type & Industry & Firm \\
\hline \multirow[t]{5}{*}{ Supplier-dominated } & \multirow[t]{2}{*}{ Wearing apparel } & $\begin{array}{l}\text { Continuum Fashion } \\
\text { Nakazato }\end{array}$ \\
\hline & & Van Herpen \\
\hline & Jewellery, bijouterie and related articles & American Pearl \\
\hline & \multirow{2}{*}{ Footwear } & Adidas \\
\hline & & Nike \\
\hline \multirow[t]{3}{*}{ Scale-intensive } & \multirow[t]{3}{*}{ Motor vehicles } & BMW \\
\hline & & Ford \\
\hline & & Urbee \\
\hline \multirow[t]{9}{*}{ Science-based } & \multirow[t]{4}{*}{ Air and spacecraft and related machinery } & Boeing \\
\hline & & GE Aviation \\
\hline & & NASA \\
\hline & & Lockheed Martin \\
\hline & \multirow[t]{3}{*}{ Medical and dental instruments and supplies } & Hearing Aid Industry \\
\hline & & Johnson \& Johnson \\
\hline & & Align Technology \\
\hline & Pharmaceutical products & Aprecia \\
\hline & Consumer electronics & New Normal \\
\hline \multirow[t]{9}{*}{ Specialised suppliers } & Knowledge Intensive Business Services & Autodesk \\
\hline & & Sketchup \\
\hline & & Turbosquid \\
\hline & & Sculpteo \\
\hline & & I-materialise \\
\hline & & Quirky \\
\hline & \multirow{3}{*}{$\begin{array}{l}\text { Industrial/business machines and material } \\
\text { suppliers }\end{array}$} & Stratasys \\
\hline & & 3D Systems \\
\hline & & $\begin{array}{l}\text { Carbon } \\
\text { DSM }\end{array}$ \\
\hline
\end{tabular}


Table 3. A new taxonomy of industrial sectors

\begin{tabular}{|c|c|c|c|}
\hline New category & Industry Sector & $\begin{array}{l}\text { Consumer } \\
\text { Involvement }\end{array}$ & $\begin{array}{l}\text { Technological } \\
\text { Content }{ }^{1}\end{array}$ \\
\hline \multirow{3}{*}{$\begin{array}{l}\text { Personalisation- } \\
\text { Dominated }\end{array}$} & Wearing apparel & High & Low \\
\hline & $\begin{array}{l}\text { Jewellery, bijouterie } \\
\text { and related articles }\end{array}$ & High & Low \\
\hline & Footwear & High & Low \\
\hline \multirow{2}{*}{$\begin{array}{l}\text { Singular Science - } \\
\text { Dominated }\end{array}$} & Motor vehicles & Low & High \\
\hline & $\begin{array}{l}\text { Air and spacecraft } \\
\text { and related } \\
\text { machinery }\end{array}$ & Low & High \\
\hline \multirow[t]{3}{*}{$\begin{array}{l}\text { Customisation- } \\
\text { Dominated }\end{array}$} & $\begin{array}{l}\text { Medical and dental } \\
\text { instruments and } \\
\text { supplies }\end{array}$ & Medium & High \\
\hline & $\begin{array}{l}\text { Consumer } \\
\text { electronics }\end{array}$ & Medium & High \\
\hline & Pharmaceutical & Medium & High \\
\hline \multirow[t]{2}{*}{$\begin{array}{l}\text { Collaborative } \\
\text { Science Dominated }\end{array}$} & $\begin{array}{l}\text { 3D printing materials } \\
\text { and equipment }\end{array}$ & None & High \\
\hline & Software & None & High \\
\hline \multirow[t]{2}{*}{$\begin{array}{l}\text { Intermediary } \\
\text { Dominated }\end{array}$} & Design & High & High \\
\hline & Online Platforms & High & High \\
\hline
\end{tabular}

\footnotetext{
${ }^{1}$ Technological content as in Castellacci's (2008) industrial taxonomy
} 